\title{
Jornalismo não tão protagonista assim
}

Janaíne Kronbauer dos Santos

\section{Janaíne Kronbauer dos}

Santos

Doutoranda em Jornalismo na Universidade Federal de Santa Catarina.

E-mail: sjanaines@gmail.com

OLIVEIRA, Dennis de. Jornalismo e emancipação: uma prática jornalística baseada em Paulo Freire. Curitiba: Appris Editora, 2017. 217 p.

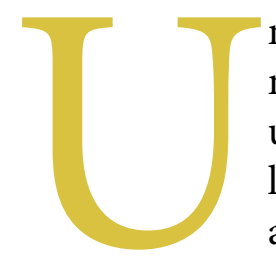

m livro que faça referência à possível intersecção entre jornalismo, emancipação e Paulo Freire já em seu título é, sem dúvidas, uma proposta que cativa a atenção de um potencial leitor/interlocutor - especialmente em dias com tons tão acinzentados para a democracia como os atuais. É essa, em princípio, a proposta de Dennis de Oliveira em sua recente obra, esmiuçada em cinco capítulos e baseada em sua tese para o concurso de livre-docência na Escola de Comunicações e Artes da USP: Jornalismo e emancipação: uma prática jornalística baseada em Paulo Freire.

$\mathrm{O}$ autor transita entre os vértices que conformam um mundo globalizado no período pós-Guerra Fria para revelar a face perversa a partir da qual se edifica o modo de produção capitalista na contemporaneidade: a associação entre os poderes constituídos e sua articulação com as tecnologias de informação e comunicação. Para o autor, experimenta-se hoje aquilo que ele denomina de "ação direta do capital" (p. 57) - conceito originário do movimento anarquista e que via na "ação direta" o seu objetivo final. Redimensionado, agora, o conceito se propõe à defesa do capitalismo a todo e qualquer custo, isolando, inclusive, seu ativismo da perspectiva política do poder em âmbito global: é um momento de desregulação e desintermediação no ambiente social.

Ao longo de densas páginas iniciais e fazendo uso de citações diretas extensas (recurso utilizado por toda a obra), o autor faz um recorte a partir de clássicos como Freud, Marx, Foucault e Bauman para pensar nos mecanismos de controle social e suas particularidades. De Freud, traz as definições em torno de "limpeza e ordem" e também de "regulação entre os seres humanos"; de Foucault, a noção de "dispositivo" e de "esquadrinhamento" dos corpos humanos para obtenção do "controle" e da "disciplina"; já de Marx, são recuperadas suas reflexões sobre o "modo de produção" e o consumo da sociedade, processo marcadamente cíclico e intermitente, com efeitos no próprio perfil identitário dos indivíduos. Finalmente, com Bauman são apresentados os "deslocamentos" na "sociedade líquida", quando "consolida-se o que se pode chamar de uma ação direta do capital" (p. 57), com inconstância e ausência de qualquer estabilidade.

Ao tratar do "triplo poder" constituído pelos monopólios de dinheiro, armas e mídia, Oliveira apresenta, no segundo capítulo da obra, o momento em que a globalização passou, além de polarizar posições identitárias e culturais entre nações, a edificar o espaço em que o neoliberalismo tomaria posição soberana, com um Estado cada vez menor, práticas de maximização do lucro, precarização 
acentuada das relações de trabalho e, tão impactante quanto as demais características, um movimento de adesão generalizada ao conservadorismo. É nesse cenário que ocorre, como pode ser visto claramente no Brasil contemporâneo, por exemplo, o esvaziamento do espaço e do debate público e a espetacularização das ações dos poderes constituídos, numa quase atualização da política romana de "pão e circo".

O terceiro capítulo de Jornalismo e emancipação é o trecho mais longo da obra, dedicado a tratar dos efeitos cruéis da "ação direta do capital" sobre o jornalismo. É também nele que se destacam dois estudos realizados pelo autor (sobre a cobertura jornalística nacional e estrangeira das eleições presidenciais de 2010 e sobre a presença estereotipada dos negros em revistas brasileiras), que atestariam a efetividade daquilo que se afirmou ao longo da obra até aquele ponto. Apesar da riqueza das informações reveladas, o texto poderia ser mais fluido, dada a diversidade de elementos ali contidos. Além disso, a busca por seu entrelace ao contexto da narrativa, por mais óbvia que possa parecer, mereceria uma maior atenção - seja para aparar arestas ou para efetivamente conferir unidade ao conjunto do capítulo (que por um instante parece apresentar de modo igualitário questões que necessariamente não o são e têm origem em lugares distintos).

Ainda assim, a crítica apresentada é de relevância incontestável, pois recupera elementos que podem ser ignorados propositalmente e que têm relação umbilical com o atual estado em que se encontra a prática do "jornalismo hegemônico" no país, ponto que é abordado no capítulo seguinte, intitulado "Dilemas do jornalismo na sociedade capitalista". É nesse quarto momento do livro que o autor apresenta a ideia de capitalismo como "civilização mundial" (p. 164), ancorado nas proposições de Comparato. Também em seu penúltimo capítulo, Dennis de Oliveira alude a autores (dentre os quais Genro Filho, Guy Debord, Baudrillard, Gramsci e Hannah Arendt) que podem auxiliá-lo na tarefa de desvelar a intricada articulação hoje existente na sociedade e que acaba por vitimar, ainda que de modo velado, a democracia. Oliveira propõe que o agente principal da narrativa jornalística hegemônica esteja sendo deslocado da autoridade para a celebridade, em um esquema orquestrado pelo capitalismo em uma fase de renovação, que faz uso, inclusive, de uma "violência sistêmica" (p. 177) para operar.

\section{Cereja do bolo}

Em seu capítulo derradeiro, Dennis de Oliveira finalmente apresenta a perspectiva de "ação cultural" proposta por Paulo Freire e seu vínculo com a possibilidade de uma "práxis jornalística emancipatória" (p. 187). Para o autor, a potencialidade transformadora do jornalismo somente pode ocorrer a partir de uma produção alicerçada em maior criticidade sobre os processos sociais reportados e a adoção de uma prática jornalística propositiva, de viés eminentemente emancipatório. Nesse sentido, pensar na adequação do lead jornalístico para outras perguntas-chave ("por que aconteceu isso que aconteceu?" e "por que não aconteceram outras coisas?") figura também como um instrumento de ação assaz potencial.

Ao fazer alusão a outros autores que seguem a mesma linha de pensamento de Paulo Freire, como Oscar Jara e Martin Baró, Dennis de Oliveira complementa suas reflexões para evidenciar que, fatalmente, o jornalismo não é a solução para todos os problemas existentes na esfera social. No entanto, esse pode ser um espaço para a visualização da complexidade a ela inerente e, especialmente, pode fomentar o desenvolvimento de um olhar mais perspicaz e crítico acerca dessa mesma realidade. 
Além desse debate ter ficado circunscrito à última parte do livro, deixando o leitor com a sensação de "inacabamento" - para fazer uso de uma expressão freireana -, uma dúvida persiste e acaba por não ser respondida: de que modo ao jornalista é possível assumir essa posição se também ele é refém do sistema instituído? Uma fórmula mágica certamente inexiste. O simples fato de ser instilada essa possibilidade pode fazer surtirem efeitos práticos? É a pergunta da vez. 